\title{
Efficacy of fungicides and bio-pesticide against the Sclerotinia sclerotiorum causing Sclerotinia rot of Mustard
}

\author{
N. K. Singh ${ }^{1}$, R. B. Singh ${ }^{1}$ and Vikas Singh ${ }^{2}$ \\ ${ }^{I}$ Department of Plant Pathology, N. D.U.A.T., Kumarganj, Faizabad, 224 229(India) \\ ${ }^{2}$ Department of Livestock Production Management, College of Veterinary, N.D.U.A.T., Kumarganj, Faizabad,
} 224229 (India)

\begin{abstract}
Two methods were used for evaluating of fungicides. In case of in vitro condition all the fungicides, and bio pesticide were significantly superior over control in inhibiting the growth of the pathogen Vitavax (0.1 $\%)$, Bavistin (0.1\%) and Benomyl (0.1\%) each were the most effective as they completely inhibited (100\%) the growth of pathogen. Whereas Neemark $(0.5 \%)$ was noted as least effective bio pesticide which inhibited the growth of fungus only upto $44.44 \%$. Ridomyl $(0.2 \%)$ and Chlorothalonil $(0.2 \%)$ were found to be the next best in superiority in inhibiting the growth of the pathogen. The spraying of Vitavax (0.1\%) at an interval of 10 days was found more effective under field condition as is evident from its corresponding yield in both the years. The next best fungicide Bavistin (0.1\%) was found statistically at par with Vitavax (0.1\%) in respect of reduction in disease severity and enhancement of seed yield. However, Neemark (0.5\%) proved to be the least effective under field condition also. Benomyl @ $0.1 \%$ ranked $3^{\text {rd }}$ in effectiveness which was significantly superior with other tested fungicides such as Indofil M-45 (0.25), Ridomyl and Chlorothalonil in respect of decreasing the disease severity but was at par in respect of seed yield.
\end{abstract}

keywords: disease, pathogen, pesticides, sclerotina sclerotorum,brassica juncea

\section{Introduction}

Indian mustard [Brassica juncea (L.) Czern. \& Coss.] Commonly known as "rai" is most important oil yielding crucifer crop belongs to family Brassicaceae. The rapeseed - mustard group accounts for $24 \%$ of the total oil seed production of which Indian mustard alone covers about $70 \%$. The crop is grown extensively in Rajasthan, Maharashtra, U.P., Gujarat and Punjab. Brassica juncea is erect, much branched, $33^{`}$ to 6 ' high annual plant with slender and tapering root. The stem branches from the axil of the fourth or fifth leaf upward. Lower leaves petiolated, green, sometimes with a whitish bloom, ovate to obovate, variously lobed with toothed, scalloped or frilled edges, lyrate-pinnatisect, with 1-2 lobes or leaflets on each side and a larger sparsely sectose, terminal lobe. Upper leaves sub-entire, short stalked, 30-60 mm long, 2-3.5 mm wide, the fruit is siliqua. The pods are bi-locular with a false septum between two halve. The oil content varied from 37 to 47 per cent in different species of rapeseed-mustard. In India, mustard ravaged by several major diseases viz. Alternaria blight (Alternaria brassicae), White rust (Albugo candida), Powdery mildew (Erysiphe cruciferarum) and Sclerotinia rot (Sclerotinia sclerotiorum) which influences the quantity and quality of yield. The pathogen affects many crops in India, particularly rapeseed-mustard and has become a widespread and destructive in mustard growing parts (Ghasolia et al., 2004) and take a heavy toll of yield (Chauhan et al., 1992). In mustard growing areas, this disease led to complete crop failure, as the disease incidence has been recorded up to 80 per cent in some parts of Punjab and Haryana states (Kang and Chahal, 2000; Sharma et. al., 2001).

\section{Materials and methods}

The studies were conducted during rabi season in department of plant pathology and Student Instructional Farm of Narendra Deva University of Agriculture and Technology, Kumarganj, Faizabad. Six fungicides belonging to different groups and one bio-pesticide were bio-assayed against the pathogen under laboratory condition to find out their relative efficacy in inhibiting the growth of the pathogen by the "Food poison technique", (Schmitz, 1930). Requisite quantity of each fungicide and bio-pesticide was incorporated in 2.0 per cent Potato Dextrose Agar medium, thoroughly mixed by shaking, prior to pouring in Petri dishes. The medium was allowed to solidify and then inoculated with $5.0 \mathrm{~mm}$ disc of inoculums from 3 days old culture of the pathogen. The inoculums was placed in the centre of each Petri dish. The fungal discs were reversed so that the pathogen could come in direct contact with the medium. Three replications were kept for each treatment. The efficacy of various fungicides and bio-pesticide were observed by measuring the redial growth of the fungal colony in $\mathrm{mm}$. The per cent inhibition over control was calculated by following formula given by Bliss (1934).

$$
\text { C-T }
$$

Per cent inhibition over control $=\quad-\quad--------100$

$\mathrm{C}$ 
Where, $\quad \mathrm{C}=$ Growth of fungus in control.

$\mathrm{T}=$ Growth of fungus in treatment

For evaluating the efficacy of various, fungicides and bio-pesticide as spray against the disease, the experiment was conducted in the field. The mustard cv. Varuna was sown in plots during both the years. Crop was inoculated artificially with $5 \mathrm{~mm}$ discs of inoculums from 3 days old culture of the pathogen. The first spraying of, fungicides and bio-pesticide was given as soon as the disease was noticed and subsequent two sprayings were followed at 10 days interval. The controlled plots were sprayed with water only. The observations on disease severity were recorded after 10 days of the last spraying and yield data were also recorded separately in each treatment after the harvest of the crop.

\section{Results and discussions}

Results presented in Table-1 indicated that all the fungicides and bio-pesticide were significantly superior over control in inhibiting the growth of the fungal colony. Vitavax $(0.1 \%)$, Bavistin $(0.1 \%)$ and Benomyl $(0.1 \%)$ were most effective as they completely inhibited $(100 \%)$ the growth of pathogen. Whereas, bio-pesticide Neemark (0.5\%) was noted as least effective and inhibited the growth of fungus only up to 44.44 $\%$. Ridomyl $(0.2 \%)$ and Indofil M-45 $(0.25 \%)$ were found to be the next best in superiority in inhibiting the growth of the pathogen Fig 1, 2 and 3. The results presented in Table-2 indicated that all the fungicides and bio-pesticide proved significantly effective in controlling the disease over control. The spraying of Vitavax $(0.1 \%)$ at an interval of 10 days was found more effective under field condition as is evident from its corresponding yield in both the years. The next best fungicide Bavistin $(0.1 \%)$ was found statistically at par with Vitavax $(0.1 \%)$ in respect of reduction in disease severity and enhancement of seed yield. However, Neemark $(0.5 \%)$ proved to be the least effective under field condition also. Benomyl @ $0.1 \%$ ranked $3^{\text {rd }}$ in effectiveness which was significantly superior with other tested fungicides such as Indofil M-45, Ridomyl and Chlorothalonil in respect of decreasing the disease severity but was at par in respect of seed yield. On the basis of average yield of both the years and additional cost involved in each treatment, the benefit-cost ratio was calculated. It was recorded that Bavistin @ 0.1\% was found most economical with benefit-cost ratio of 1:2.59 followed by Indofil M-45 @ 0.25\% (1:1.57) and Vitavax @ 0.1\% (1:1.38), respectively. Vitavax, was found most effective in controlling the disease and increasing the seed yield in comparison to others, but due to its high cost of product it ranked third after Dithane M-45 which was less effective. Similarly, Benomyl which ranked third in effectiveness was also lower in benefit-cost ratio and ranked fourth (1:0.90) due to its high product price. Among the chemicals, the benefit- cost ratio of Ridomyl was recorded lowest (Table-3), though it was at par with Indofil M-45 (0.25) in effectiveness. Neemark was recorded overall least effective with lowest benefitcost ratio (1:0.21).

Concurrent with present findings i.e. much effectiveness of Vitavax $(0.1 \%)$ against the inhibition of mycelia growth of Sclerotinia sclerotiorum was also reported by earlier workers time to time (Singh and Gangopadhyay,1984, Abdou et al. ,1982 and Roy and Saikia,1976) under laboratory conditions. It was observed that the performance of systemic fungicides was better in controlling the disease in comparison to nonsystemic fungicides. Singh et al. (1994) and Singh et al. (2003) have also reported the effectiveness of these fungicides. Sharma, A.K. (1987) reported that Bavistin, Benomyl, Chlorothalonil and Indofil M-45 were effective against Sclerotinia sclerotiorum on pea crop.

Table 1. Efficacy of fungicides / bio-pesticide against the growth of Sclerotinia sclerotiorum under in-vitro

\begin{tabular}{|l|c|c|}
\hline \multicolumn{1}{|c|}{ Fungicides/ bio-pesticide(\%) } & Average diameter of colony (mm) & Per cent inhibition over control \\
\hline Bavistin (0.1) & 0.0 & 100.0 \\
\hline Vitavax (0.1) & 0.0 & 100.0 \\
\hline Chlorothalonil(0.2) & 46.20 & 48.67 \\
\hline Indofil M-45 (0.25) & 36.83 & 59.08 \\
\hline Ridomyl (0.2) & 28.67 & 68.14 \\
\hline Benomyl (0.1) & 0.0 & 100.0 \\
\hline Neemark (0.5) & 50.00 & 44.44 \\
\hline Control & 90.00 & 0.00 \\
\hline CD at 5\% & $\mathbf{3 . 5 6}$ & \\
\hline
\end{tabular}


Table 2. Efficacy of fungicides / bio-pesticide against the Sclerotinia sclerotiorum under in vivo.

\begin{tabular}{|c|c|c|c|c|c|}
\hline \multirow[b]{2}{*}{ Fungicides/ biopesticide (\%) } & \multicolumn{2}{|c|}{$1^{\text {st }}$ year } & \multicolumn{2}{|c|}{$2^{\text {nd }}$ year } & \multirow{2}{*}{$\begin{array}{l}\text { Av. yield of } \\
\text { both years }\end{array}$} \\
\hline & $\begin{array}{c}\text { Disease } \\
\text { severity }(\%)\end{array}$ & Yield (q/ha) & $\begin{array}{c}\text { Disease } \\
\text { severity }(\%)\end{array}$ & Yield (q/ha) & \\
\hline Bavistin (0.1) & 8.00 & 10.83 & 9.33 & 10.33 & 10.58 \\
\hline Chlorothalonil (0.2) & 18.67 & 8.33 & 17.33 & 6.66 & 7.49 \\
\hline Indofil M-45 (0.25) & 21.33 & 7.5 & 22.67 & 7.50 & 7.50 \\
\hline Ridomyl (0.2) & 20.00 & 7.08 & 22.67 & 8.66 & 7.87 \\
\hline Neemark $(0.5)$ & 24.00 & 5.83 & 28.67 & 5.83 & 5.83 \\
\hline Control & 39.50 & 5.00 & 38.33 & 5.20 & 5.10 \\
\hline CD at $5 \%$ & 5.10 & 2.65 & 4.80 & 2.66 & 2.85 \\
\hline
\end{tabular}

Table.3 Economics of fungicides/ bio-pesticide.

\begin{tabular}{|c|c|c|c|c|c|c|c|c|}
\hline Particulars & Control & $\begin{array}{l}\text { Bavistin } \\
(0.1 \%)\end{array}$ & $\begin{array}{l}\text { Vitavax } \\
(0.1 \%)\end{array}$ & $\begin{array}{l}\text { Indofil M- } \\
45 \\
(0.25 \%)\end{array}$ & $\begin{array}{l}\text { Chlorothalon } \\
\text { il }(0.2 \%)\end{array}$ & $\begin{array}{l}\text { Benomyl } \\
(0.1 \%)\end{array}$ & $\begin{array}{l}\text { Ridomyl } \\
(0.2 \%)\end{array}$ & $\begin{array}{l}\text { Neemark } \\
(0.5 \%)\end{array}$ \\
\hline $\begin{array}{l}\text { Amount of } \\
\text { fungicides } \\
\text { /bio- } \\
\text { pesticide kg/ } \\
\text { ha }\end{array}$ & - & 3 & 3 & 6 & 6 & 3 & 6 & 15 \\
\hline $\begin{array}{l}\text { Cost of } \\
\text { fungicides } \\
\text { (Rs.) }\end{array}$ & - & 2210 & 6000 & 1488 & 1500 & 6000 & 8700 & 3600 \\
\hline $\begin{array}{l}\text { Sprayer } \\
\text { charges } \\
(15 R s / d a y s)\end{array}$ & - & 45 & 45 & 45 & 45 & 45 & 45 & 45 \\
\hline $\begin{array}{l}\text { Labour } \\
\text { charges } \\
\text { ( Rs. 58/ } \\
\text { day) }\end{array}$ & - & 522 & 522 & 522 & 522 & 522 & 522 & 522 \\
\hline $\begin{array}{l}\text { Total cost } \\
\text { (Rs.) }\end{array}$ & - & 2777 & 6567 & 2055 & 2067 & 6567 & 9267 & 4167 \\
\hline $\begin{array}{l}\text { Av. Yield } \\
\text { (q/ha) }\end{array}$ & $\begin{array}{l}5.2 \\
0\end{array}$ & 10.33 & $\begin{array}{l}11.6 \\
6\end{array}$ & 7.50 & 6.60 & 9.41 & 8.66 & 5.83 \\
\hline $\begin{array}{l}\text { Additional } \\
\text { yield over } \\
\text { control }\end{array}$ & - & 5.13 & 6.46 & 2.30 & 1.40 & 4.21 & 3.46 & 0.63 \\
\hline $\begin{array}{l}\text { Net income } \\
\text { Rs. / ha }\end{array}$ & $\begin{array}{l}72 \\
80\end{array}$ & 7182 & 9044 & 3220 & 1960 & 5894 & 4844 & 882 \\
\hline $\mathrm{C}: \mathrm{B}$ ratio & - & $1: 2.59$ & $1: 1.38$ & $1: 1.57$ & $1: 0.95$ & 1:0.90 & $1: 0.52$ & $1: 0.21$ \\
\hline
\end{tabular}

Sale price of mustard: Rs. 1400/q

References:

[1]. Abdou, Y.A.M.; Fl. Sharkaway, T.A.; Osman, A.R. and Ragab, M.M. (1982). In vitro test for control of Sclerotinia sclerotiorum. Egyptian J. Phtytopathology. 14: 87-92.

[2]. Anonymous, 2011. Statistical Year Book India. Directorate of Economics and Statistics, Ministry of Agriculture, pp: 117.

[3]. Bliss, C.I. (1934). The method of probits. Science. 79: 38.

[4]. Chauhan, L.S., Singh, Jyoti and D.R.Chandra, 1992: In: proc. Natl. Symp. On management Microbes in Service of Mankind". Nov. 19-21,1992 at Univ. Allahabad, India. 65-66 pp (Abstr.).

[5]. Chandel, S.R.S. (1993). A hand book of Agriculture statistics. Achal Prakashan Mandir, Kanpur, pp 558

[6]. Ghasolia, R.P., Shivpuri, Asha and A.K. Bhargava, 2004: Sclerotinia rot of Indian mustard (Brassica juncea) in Rajasthan. Indian Phytopath.57: 76-79.

[7]. Kang, I.S. and S.S. Chahal, 2000: Prevalence and incidence of white rot of mustard incited by Sclerotinia sclerotiorum in Punjab. Plant Dis. Res. 15: 232-233.

[8]. Roy, A.K. and Saikia, V.N. (1976). White blight of mustard and its control. Indian J. of Agric.Sci. 46 (6): $274-277$.

[9]. Schmitz, H. (1930). A suggested toximetric method for wood preservative Indus. Engin Chem., Anlyt. Edi II. 361-363. Rev. Appl. Mycol. 10: 21-1931.

[10]. Sharma, S., J.L. Yadav and G.R. Sharma, 2001: Effect of various agronomic practices on the incidence of white rot of Indian mustard caused by Sclerotinia sclerotiorum J.Mycol. Pl. Pathol 31: 83-84.

[11]. Singh, N. and Grangopadhyay, S. (1984). Control of white rot seed cauliflower. Pesticides. 18: 23- 24.

[12]. USDA., 2010. United States Department of Agriculture-Rapeseed are, yield and production Table No.15 http:// www. Fas.usda.gov/psd online/ psd report. Asps (created on july 3, 2010). 

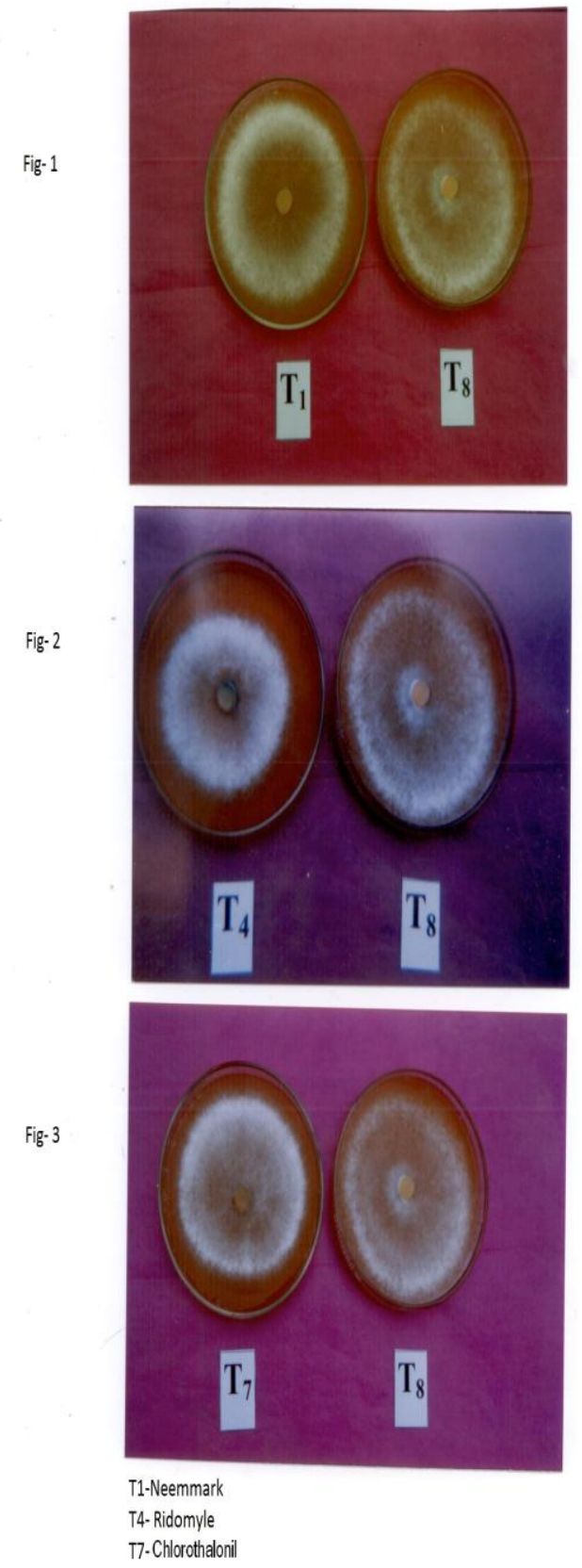

Fig.1,2,3:Effect of different fungicides against the pathogen (Scelerotinia sclertiorum) under in vitro. 